\title{
MYOCARDIAL TRANSFER OF SODIUM AND POTASSIUM: EFFECT OF ACETYL STROPHANTHIDIN IN NORMAL DOGS ${ }^{1,2}$
}

\author{
By TIMOTHY J. REGAN, ${ }^{3}$ FREDERICK N. TALMERS, ${ }^{4}$ AND \\ HARPER K. HELLEMS
}

\begin{abstract}
(From the Cardiovascular Research Laboratory, Department of Medicine, Wayne State University College of Medicine and City of Detroit Receiving Hospital, Detroit, Mich.)
\end{abstract}

(Submitted for publication January 3, 1956; accepted July 25, 1956)

Although the hemodynamic events attending low-output congestive heart failure have been well defined, the biochemical changes in the myocardium responsible for these events and the response to cardiac glycosides remain largely unknown. Evidence to date suggests that in the failing heart there is normal substrate oxidation but an impairment of energy utilization (1). Recent data would indicate an altered state of the myocardial protein-complex, actomyosin (2), but whether this is the primary event in the evolution of congestive failure remains to be demonstrated.

Post-mortem tissue analyses for cation content of human heart muscle in failure have shown a lowered content of potassium $(3,4)$. Moreover, after digitalis, in therapeutic (5) and toxic doses $(5,6)$, the potassium content diminishes, although some disagreement over the former exists. That these changes may have functional significance is suggested by the work of Hajdu (7), who, from data obtained with a frog heart-muscle preparation, has inferred that the positive inotropism of digitalis is effected by the reduction in internal ionic content produced by the transfer of potassium from the cell.

The pronounced effect of digitalis on the mechanical efficiency of the failing myocardium (8, 9) suggests that this drug might provide data re-

1 Presented in part at the Forty-Seventh Annual Meeting of the American Society for Clinical Investigation, Atlantic City, May 2, 1955.

2 This investigation was supported by Grant H-1492, National Heart Institute, National Institutes of Health, U. S. Public Health Service; Grant 1 B, Michigan Heart Association; and by the Receiving Hospital Research Corporation.

8 Public Health Research Fellow of the National Heart Institute (1954-1956).

4 Public Health Research Fellow of the National Heart Institute (1953-1955); at present Research Associate, supported in part by the Michigan Heart Association. lating the movement of myocardial cations to cardiac hemodynamic function in vivo. Consequently, a study of these parameters was undertaken in the experimental animal, employing the rapid-acting digitalis analogue, acetyl strophanthidin.

\section{METHODS}

The experimental design of this study involves assumptions which appear sufficiently valid to justify their use. The coronary arterio-venous (A-V) differences of sodium and potassium were employed as a measure of their net uptake by, or release from, the myocardium. It is assumed that the shifting ions move quickly enough across the capillary to result in almost instant equilibration between interstitial fluid and effluent plasma (10). Whereas increased blood flow will dilute down or diminish $\mathrm{A}-\mathrm{V}$ difference, decreased flow will augment it. Although no measurements of coronary blood flow have been made after strophanthidin, a separate study has revealed no change in myocardial oxygen $A-V$ difference after this drug, suggesting that substantial changes in coronary flow do not occur. In other unpublished work, we have increased coronary blood flow by other experimental means and noted no change in electrolyte A-V difference. Thus we feel that the coronary flow changes accompanying strophanthidin dosage are insufficient in magnitude to bring about the electrolyte A-V differences to be reported.

Eight mongrel male dogs, weighing 14 to 21 kilograms, were anesthetized with sodium pentobarbital, $25 \mathrm{mg}$. per kg., supplemented as needed to maintain light anesthesia. A Cournand needle was placed in the femoral artery and single lumen catheters, filled with heparin, were placed via the external jugular vein in the coronary sinus to obtain blood samples and in the right auricle for injection of the drug. Heparin, $5 \mathrm{mg}$. per kg., was administered to prevent clotting, and pure oxygen delivered into an endotracheal tube to exclude the effects of hypoxia on plasma electrolytes (11).

Acetyl strophanthidin, ${ }^{5}$ dissolved in 60 per cent ethyl alcohol ( $0.5 \mathrm{mg}$. per cc.) was infused into the right auricle in dosage of 0.05 to $0.1 \mathrm{mg}$. per $\mathrm{kg}$. in volumes of

\footnotetext{
${ }^{5}$ Kindly supplied by Dr. Kenneth G. Kohlstaedt, Medical Department, Eli Lilly and Company, Indianapolis, Indiana.
} 
MYOCARDIAL TRANSFER OF SODIUM AND POTASSIUM

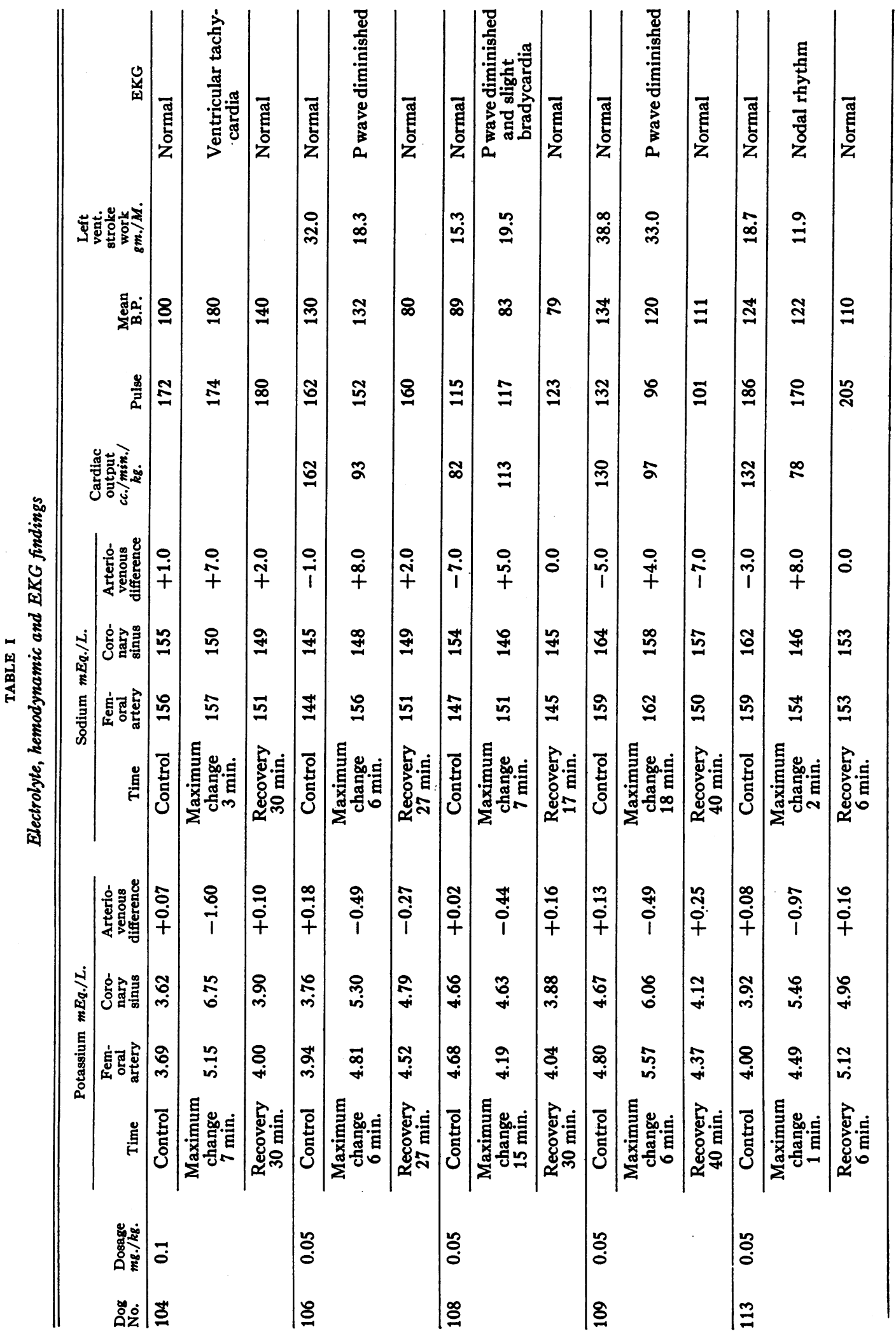




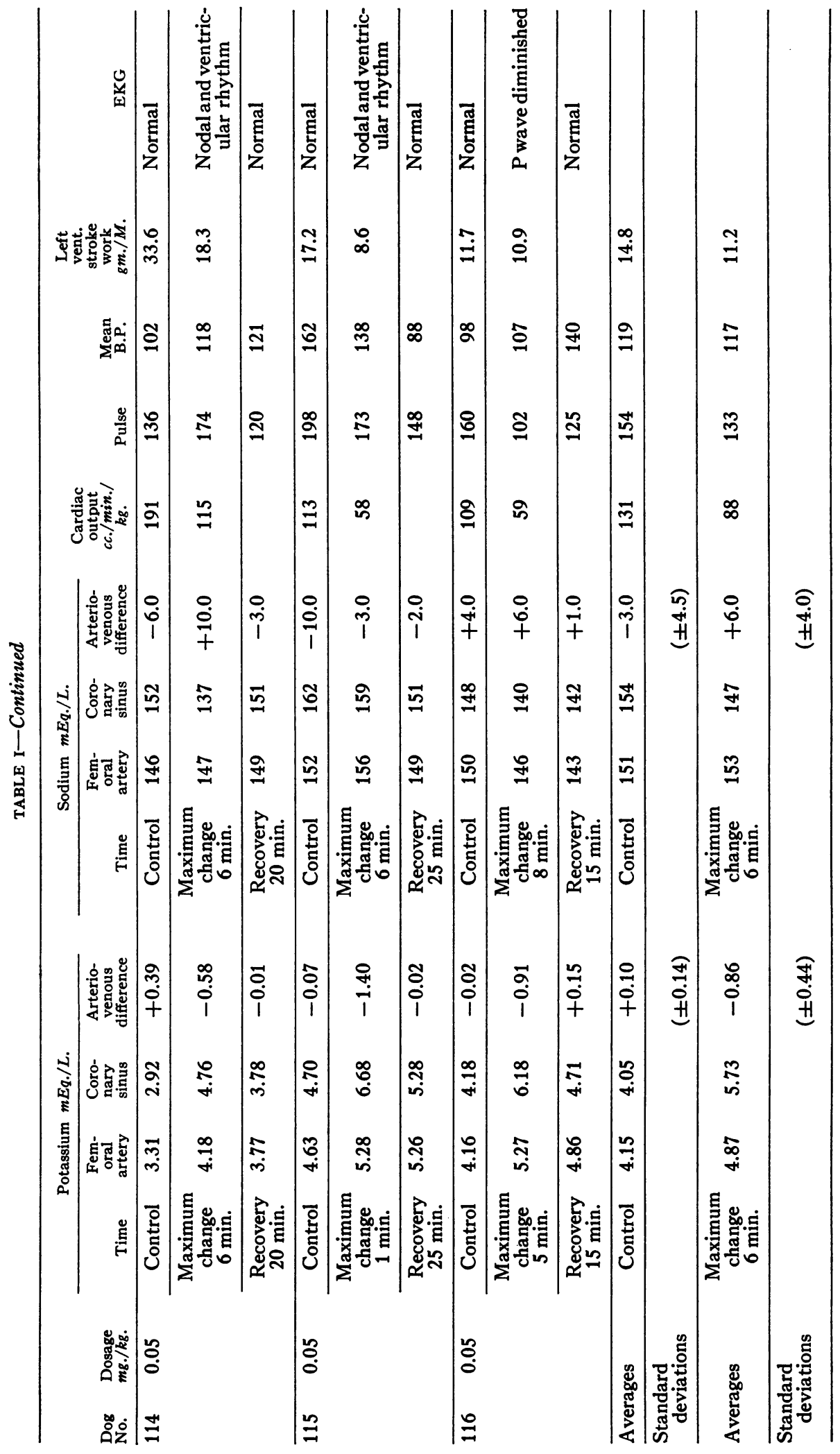


0.6 to $1.0 \mathrm{cc}$. over a period of 15 seconds. This rapid acting aglycone was selected so that its abrupt and short duration of action (12) might facilitate detection of electrolyte changes in coronary sinus blood, which might otherwise not be found with slower acting preparations. The hemodynamic properties of this drug appear to be qualitatively the same as the glycoside, Ouabain $(13,14)$, and it is presumed that its physical chemical properties are not essentially different.

Determination of cardiac output by a modification (15) of the Stewart-Hamilton dye method was made 10 to 20 minutes prior to drug injection and 10 minutes after, at which time, the hemodynamic effects of the drug are near maximal (12). Phasic and mean arterial pressures were obtained at 5-minute intervals with a Sanborn electromanometer and recorded on the Sanborn polyviso. Stroke work against pressure was calculated as the product of the mean femoral artery pressure and stroke output, and expressed in gram-meters (16). The electrocardiogram (Lead $A V_{F}$ ) was recorded on the polyviso just prior to giving the drug and at one-minute intervals for 15 minutes; thereafter, at 5-minute intervals until the control state was re-established. The respiratory rate was noted simultaneously.

Eight milliliters of whole blood were drawn in chemically clean, dry syringes simultaneously from the coronary sinus and femoral artery for control electrolyte samples, 2 to 10 minutes before drug administration. In four dogs, two sets of controls were drawn 10 to $15 \mathrm{~min}$ utes apart and were not significantly different. After strophanthidin injection through the right auricular catheter, 8 milliliter samples were taken from artery and coronary sinus at $2,5,8,15,30,45,60$, and occasionally at 90 , and 120 minutes. Timing was not precise in some instances, but remained simultaneous. After centrifuging at 1,500 r.p.m. for 20 minutes, plasma determinations of sodium and potassium were done on a Beckman flame photometer, with an error of less than 2 per cent on duplicate readings. The occasional hemolyzed samples were discarded. In four experiments, simultaneous blood samples from the artery and coronary sinus were secured in oiled syringes containing small amounts of heparin for immediate delivery to a Beckman glass-electrode $\mathrm{pH}$ meter maintained at constant temperature of $38^{\circ}$ in the water bath, and in which duplicate readings agreed to $0.02 \mathrm{pH}$ unit. Samples were taken during control periods and at 2,8 , and 15 minutes. Hematocrits were run on the same samples.

In determining the statistical significance of the electrolyte changes, utilizing standard methods (17), the maximum change in $\mathrm{A}-\mathrm{V}$ difference of sodium and potassium was selected and compared with the control A-V difference. Intervening $\mathrm{A}-\mathrm{V}$ differences generally represented increasing and decreasing gradations of these maximum values, as shown in Figure 1 . The variability in time of occurrence of this maximum change is probably consistent with the variability of the hemodynamic time-response to cardiac glycosides. The figures for recovery, given in Table I, signify the first A-V dif-

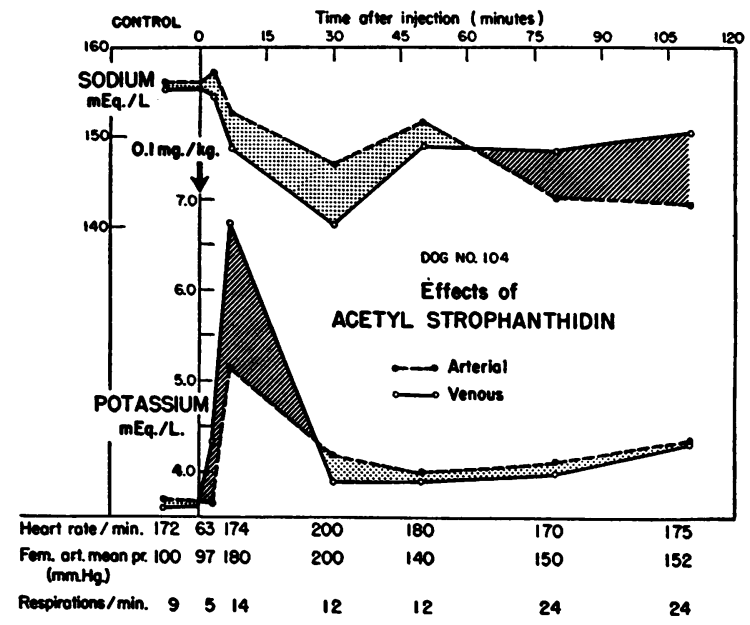

Fig. 1. Myocardial Cation Exchange in an INdividual Experiment Typical for Group Illustrating Sequential Changes after Acetyl Strophanthidin

Venous refers to coronary sinus blood. Arterial refers to systemic artery. Stippling indicates positive A-V difference or myocardial uptake and diagonal shading indicates negative $\mathrm{A}-\mathrm{V}$ difference or release of cation.

ference values after the maximum response to approximate the control values.

\section{RESULTS}

A typical individual experiment of this study is depicted in Figure 1, demonstrating the acuteness of the cation responses and their divergent movement as illustrated by the simultaneous positive sodium and negative potassium $\mathrm{A}-\mathrm{V}$ differences. The reversal of these initial changes after $30 \mathrm{~min}$ utes, as seen in this experiment, was not a consistent finding in the group as a whole. The mean control potassium values for the group were 4.15 $\pm .52 \mathrm{mEq}$. per $\mathrm{L}$. in the artery, and $4.05 \pm .62$ $\mathrm{mEq}$. per L. in the coronary sinus, so that the mean $\mathrm{A}-\mathrm{V}$ difference of $0.10 \pm .14$ was not significant in view of the error of determination. After the infusion of acetyl strophanthidin, there was, as shown in Figure 2, an abrupt loss of potassium in seven animals, a somewhat slower loss in the eighth, with the maximum change occurring in an average of six minutes for the group. The mean arterial potassium at this time was $4.87 \pm$ $0.53 \mathrm{mEq}$. per L., and the coronary sinus value $5.73 \pm 0.82 \mathrm{mEq}$. per L., so that a mean negative $\mathrm{A}-\mathrm{V}$ difference of $0.86 \pm .44 \mathrm{mEq}$. per $\mathrm{L}$. was present, which, when subject with the control values to the $t$ test, was found significant $(P=<$ 


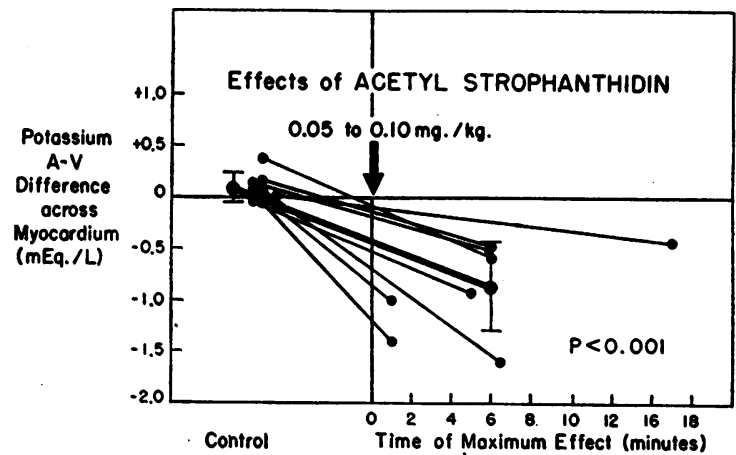

Fig. 2. The Effect of Acetyl Strophanthidin on Potassium A-V Difference

Control and maximum $\mathrm{A}-\mathrm{V}$ differences in individual animals represented by closed circles. Mean values for group represented by targets. Brackets indicate standard deviation.

$.001)$. There was in general a less rapid reversion to control values of the potassium A-V difference (Figure 4), but variation was evident with a range of 6 to 50 minutes (Table I). The rise in arterial potassium was greater than could be accounted for by myocardial loss alone and presumably was derived from skeletal muscle in accord with previous tissue studies (3).

The mean value for the control arterial sodium was $151 \pm 6 \mathrm{mEq}$. per L., and for the coronary sinus $154 \pm 8 \mathrm{mEq}$. per L., so that a slight negative $A-V$ difference of $-3 \pm 4 \mathrm{mEq}$. per L. was present. As seen in Figure 3, approximately concurrent with the potassium loss from the myocardium and despite the varied control values, there occurred increasing positivity of the A-V difference in each case, suggesting uptake of sodium. The mean $\mathrm{A}-\mathrm{V}$ difference at the point of maximal change was $+6 \pm 4 \mathrm{mEq}$. per L., which represents an increase of about $9 \mathrm{mEq}$. per L. over the control state. The arterial value was $153 \pm$ $5 \mathrm{mEq}$. per L., the coronary sinus, $147 \pm 8 \mathrm{mEq}$. per L. A comparison with the control figures gave a $P$ value of $<0.01$. Reversion to negligible $\mathrm{A}-\mathrm{V}$ difference required, as with potassium, a variable time ranging from 6 to 50 minutes. Although more precise electrolyte measurement would be preferable, it would appear from the graphing of the composite values seen in Figure 4 that there was excess sodium ingress over potassium loss, suggesting that the ionic content of the myocardium increased, or that other cation was lost

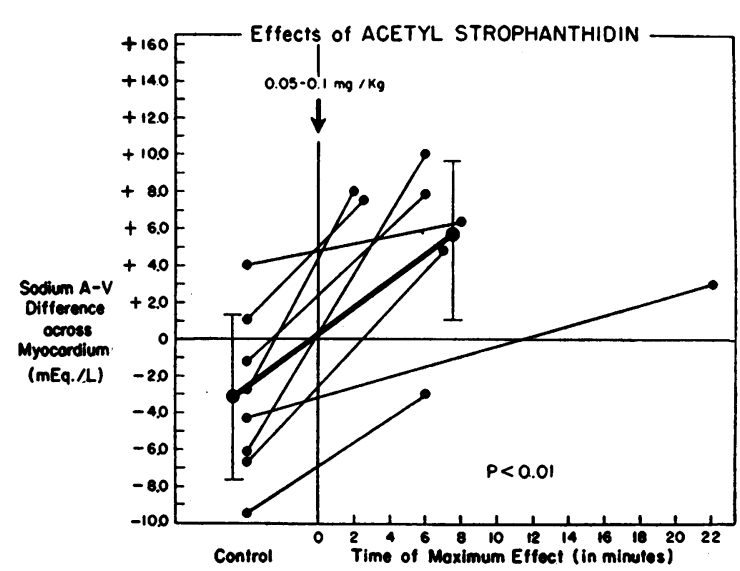

Fig. 3. The Efrect of Acetyl Strophanthidin on SODIUM A-V Difference

Symbols same as in Figure 2.

if this represents a complete exchange phenomenon.

The transient respiratory depression induced by the drug reduced ventilation by about 80 per cent for thirty seconds with rapid recovery and was accompanied by a decline in mean arterial $\mathrm{pH}$ from 7.46 to 7.36 in the 4 animals in which this was measured. In two dogs in whom there was no significant change in $\mathrm{pH}$, electrolyte changes were of the same order as those with a substantial fall. Moreover, in another study (18), the same ionic changes were seen in animals in which respiratory alteration was prevented by vagotomy.

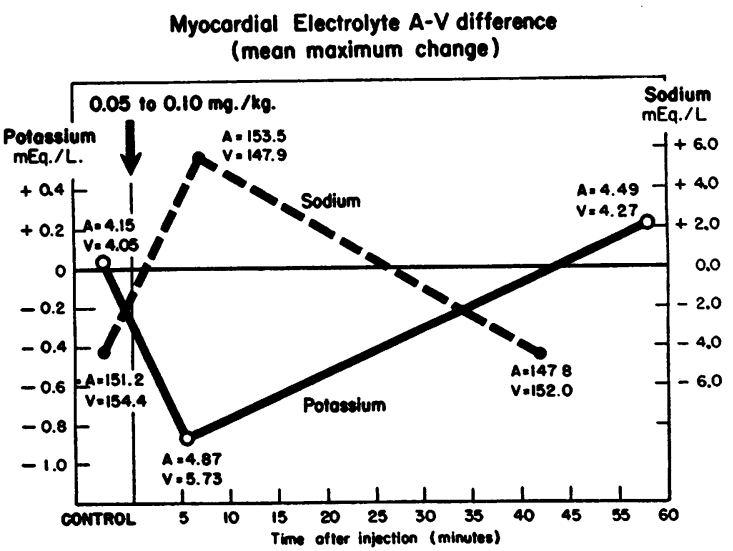

Fig. 4. Composite of Control, Maximum and Recovery Mean A-V Difference Values of Cations for Group

Interrupted line, sodium; solid line, potassium. A refers to arterial and V refers to coronary sinus. Mean concentration of electrolytes in $\mathrm{mEq}$. per $\mathrm{L}$. at times indicated. 
The difference between the coronary sinus $\mathrm{pH}$ and that of the arterial blood remained essentially the same during the experiment, except in the group of dogs with the more severe EKG changes, where the mean control $\mathrm{pH} \mathrm{A}-\mathrm{V}$ difference was +.05 and the maximum change was $+.11 \mathrm{pH}$ units, suggesting that the myocardium may release $\mathrm{H}+$ during the toxic response to strophanthidin.

The mean cardiac output fell from a control of $131 \mathrm{cc}$. per min. per $\mathrm{kg}$. to $88 \mathrm{cc}$. per min. per $\mathrm{kg}$. (Figure 5); the rise in one animal was apparently associated with an unsteady state, as the systemic arterial pressure was fluctuating throughout the experiment. This decrease was due to a diminished stroke volume of $14.8 \mathrm{cc}$. to $11.2 \mathrm{cc}$, and a decline in pulse rate from 154 to 133 beats per minute. Since the mean arterial blood pressure for the group remained the same, the stroke work change paralleled that of the stroke volume, decreasing from $23.8 \mathrm{gm}$. meters in the control to $17.7 \mathrm{gm}$. meters after acetyl strophanthidin.

Electrocardiographic changes in this group of animals appeared related to the magnitude of potassium transfer. Four dogs with minimal changes of bradycardia with or without $P$ wave alteration had negative potassium $\mathrm{A}-\mathrm{V}$ differences ranging from -0.44 to $-0.91 \mathrm{mEq}$. per L. (average -.58$)$. As the coronary sinus blood represents predominantly drainage from the left ven-

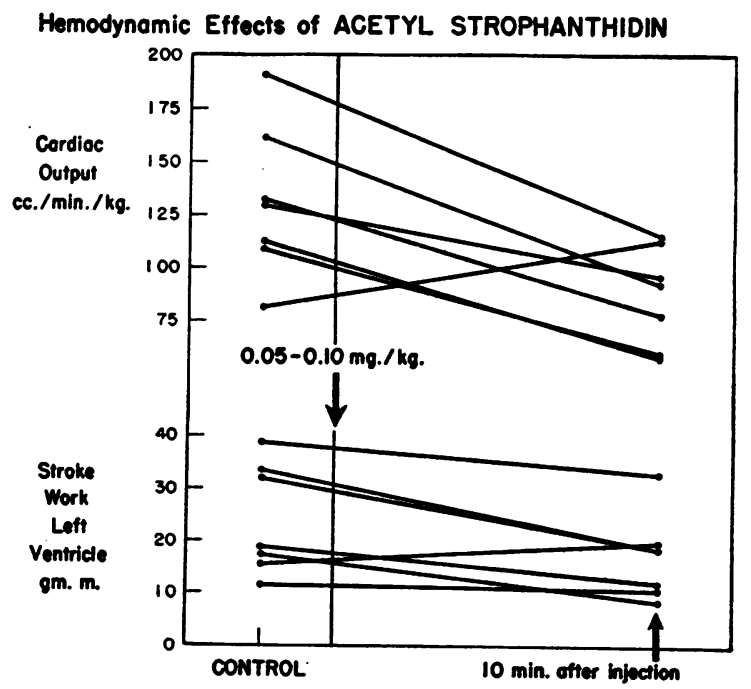

Fig. 5. The Effects of Acetyl Strophanthidin on Cardiac Output and Stroke Work tricle (19) and these animals gave no evidence of any electrocardiographic change referable to the ventricle, the potassium increment in the coronary sinus blood may be said to be derived from tissue exhibiting no electrical sign of toxicity. The four dogs with toxic electrocardiographic alterations manifested by ectopic beats, nodal and/or ventricular tachycardia had negative potassium $\mathrm{A}-\mathrm{V}$ differences of -0.58 to $-1.60 \mathrm{mEq}$. per $\mathrm{L}$. (average - 1.14). There was no correlation between the electrocardiographic changes and myocardial uptake of sodium.

No significant change in hematocrit values across the heart was observed during the course of these experiments, suggesting that there was no substantial transfer of water.

Digitalis preparations and ethyl alcohol may destroy the red cell membrane and release hemoglobin and potassium into the plasma (20). To exclude the alcohol vehicle as a cause of the observed electrolyte changes, $1 \mathrm{cc}$. of 60 per cent ethyl alcohol was injected into 3 dogs and produced no significant change in myocardial potassium $\mathrm{A}-\mathrm{V}$ difference. Plasma hemoglobin determinations (21) were performed on the same plasma used for electrolyte analysis. Although there was a slight increase in plasma hemoglobin, the calculated increase in plasma potassium of $.05 \mathrm{mEq}$. per $\mathrm{L}$. as a result of the hemolysis would not significantly modify the plasma electrolyte concentration, as would be expected from the relatively low potassium content of $10 \mathrm{mEq}$. per L. in the canine red cell (19). Moreover, if there was any prozone effect on the red cells, it is unlikely that this would distort the arterio-venous difference values of potassium in such a manner as to contribute to the changes observed.

\section{DISCUSSION}

A direct action of cardiac glycosides on heart muscle has been demonstrated in a variety of ways, ranging from the improvement in contractile force of the fatigued papillary muscle of the cat (22), to the hemodynamic studies in the human subject with congestive failure in which increase in stroke output is the primary effect of the drug (8, 9). Since this improvement in the mechanical efficiency of the failing heart in low output failure occurs without significantly altering the supply 
of chemical energy $(23,24)$, attention has been drawn to the direct action of digitalis upon the contractile protein.

That the contractile elements in heart muscle are the agents of this action has been suggested by Horváth, Király, and Szerb (25), who concluded that the basic action of the glycosides may be on the polymerization of actin prior to its union with myosin. In support of this general view, Robb and Mallov (26) have found that the actomyosin thread shortened more rapidly and to a greater degree under the influence of Ouabain. These reactions, however, might be secondary to changes in the ionic media since such changes have considerable influence upon the actomyosin system as has been suggested by Szent-Györgyi (27).

From the isolated heart muscle studies of Hajdu (7), it has been inferred that the positive inotropic, effect of digitalis depends upon the diminished internal ionic content effected by the movement of potassium from the cell. Assuming that the only alterations occurring were in those ions measured, as suggested by tissue analyses (4), the normal dog heart in this study apparently underwent an increase in internal ionic content due to the greater net uptake of sodium over egress of potassium. It would appear possible that this alteration in the intracellular ionic atmosphere may represent the physico-chemical process responsible for the decline in stroke work in the normal animal $(28$, 29). That an increment in intracellular sodium associated with potassium loss may be deleterious to the heart is borne out by studies of Cannon, Frazier, and Hughes (30), in which this electrolyte situation was produced in the rat by dietary control, resulting in areas of focal necrosis mainly in the subendocardium.

While ionic changes may be but one of the determinants of myocardial contraction, and may exist to the extent observed here only under pharmacologic influence, it is quite possible that they participate in the physiologic control of cardiac output that attends altered ventricular filling pressure and cardiac muscle stretch. Hercus, McDowall, and Mendel (31) have found that stretch of the rat left ventricle promotes sodium loss and that increase in sodium extrusion may contribute to the efficiency of stretched muscle. The diminished efficiency found following impairment of the sodium extrusion mechanism would appear to parallel the findings in this study of strophanthidin in the normal animal, in which intracellular sodium accumulation was associated with diminished stroke work. While this ionic change in both instances may be but a by-product of the altered mechanical ability of the myocardium, the observation by Ranney (32) of a direct inhibitory effect of sodium at almost all concentrations in glycerol-extracted myocardial muscle would tend to support the view of an intimate relation between sodium accumulation and impaired mechanical ability.

The myocardial potassium loss seen in these animals, quantitatively greater in the four with toxic electrocardiographic changes, compares closely to that found by Conn (33) in normal dogs after digitoxin administration and amounted to 15 per cent of the total myocardial intracellular potassium by approximate calculation. Substantially the same myocardial potassium egress has occurred in patients reacting therapeutically to strophanthidin (34) so that the reduced potassium content of the untreated failing heart reported by other workers $(3,4)$ would appear to be enhanced by glycoside therapy.

The evidence provided by Wilde, O'Brien, and Bay (35) that there is potassium transfer across the heart with each cardiac cycle, egress of this ion occurring during repolarization, raises the question whether the potassium loss induced by glycosides is but an enhancement of this normal phenomenon, since the characteristic electrocardiographic manifestations of digitalis agents also takes place during repolarization. There is, however, suggestive experimental evidence from the isotopic study of Conn (33) that the return of potassium to the cell might be impeded since a reduced influx rate was found in dogs treated with digitoxin.

As it is possible that the electrolyte changes associated with strophanthidin have no influence upon myocardial performance, it would seem important to devise a method for blocking this ionic transport, preferably in the failing heart preparation where the effects on performance are more readily discerned. Moreover, if the same ionic pattern is found in the positive inotropic response of the failing heart as is reported here in the normal heart, then the lack of specificity of these ionic changes would militate against their having 
a major role in the determination of myocardial performance.

\section{SUMMARY}

By simultaneous collection of blood samples from a systemic artery and coronary sinus, the myocardial transfer of sodium and potassium has been measured in eight anesthetized dogs before and after the administration of the digitalis analogue acetyl strophanthidin in doses of 0.05 to 0.1 mg. per $\mathrm{kg}$. To relate cation transfer to cardiac performance, cardiac stroke work was assessed during the control period and at the time of maximal drug response.

There was no significant $\mathrm{A}-\mathrm{V}$ difference of potassium during the control period. After strophanthidin, there was an abrupt increase in coronary sinus potassium with less rise in arterial potassium concentration, giving a mean maximum negative $\mathrm{A}-\mathrm{V}$ difference of $0.86 \pm 0.44 \mathrm{mEq}$. per L., indicating loss of potassium from the myocardium. Concurrently, there appeared to be a greater uptake of sodium with a positive $A-V$ difference of $6.0 \pm 4.0 \mathrm{mEq}$. per L. Both cation $\mathrm{A}-\mathrm{V}$ differences resumed approximate control values at about 30 minutes. Animals with minor EKG changes after strophanthidin had less potassium loss than those with toxic EKG changes. No such correlation with sodium was found.

The stroke work of the left ventricle in this group of animals declined from a control value of $23.8 \mathrm{gm}$. meters to $17.7 \mathrm{gm}$. meters after strophanthidin. It is suggested that the negative inotropic effect of the digitalis analogues in the normal animal may be affected by the increase in internal ionic content of the myocardium due to the greater influx of sodium over egress of potassium.

\section{ACKNOWLEDGMENT}

The authors wish to acknowledge the technical assistance of Mrs. Barbara Rinkenberger, Miss Mary R. Connor, and Mrs. Karen Massel; the secretarial services of Mrs. Shirley Loy; and the helpful advice of Bennie Zak, Ph.D.

\section{REFERENCES}

1. Olson, R. E., and Schwartz, W. B., Myocardial metabolism in congestive heart failure. Medicine, 1951, 30, 21.

2. Benson, E. S., Composition and state of protein in heart muscle of normal dogs and dogs with ex- perimental myocardial failure. Circ. Research, 1955, 3, 221.

3. Harrison, T. R., Pilcher, C., and Ewing, G., Studies in congestive failure. IV. The potassium content of skeletal and cardiac muscle. J. Clin. Invest., $1930,8,325$.

4. Iseri, L. T., Alexander, L. C., McCaughey, R. S., Boyle, A. J., and Myers, G. B., Water and electrolyte content of cardiac and skeletal muscle in heart failure and myocardial infarction. Am. Heart J., 1952, 43, 215.

5. Wood, E. H., and Moe, G. K., Electrolyte and water content of the ventricular musculature of the heartlung preparation with special reference to the effects of cardiac glycosides. Am. J. Physiol., 1942, 136, 515.

6. Calhoun, J. A., and Harrison, T. R., Studies in congestive failure. IX. The effect of digitalis on potassium content of cardiac muscle of dogs. J. Clin. Invest., 1931, 10, 139.

7. Hajdu, S., Mechanism of staircase and contracture in ventricular muscle. Am. J. Physiol., 1953, 174, 371.

8. Bloomfield, R. A., Rapoport, B., Milnor, J. P., Long, W. K., Mebane, J. G., and Ellis, L. B., The effects of cardiac glycosides upon the dynamics of the circulation in congestive heart failure. I. Ouabain. J. Clin. Invest., 1948, 27, 588.

9. Harvey, R. M., Ferrer, M. I., Cathcart, R. T., Richards, D. W., Jr., and Cournand, A., Some effects of digoxin upon the heart and circulation of man: Digoxin in left ventricular failure. Am. J. Med., 1949, 7, 439.

10. Pappenheimer, J. R., Passage of molecules through capillary walls. Physiol. Rev., 1953, 33, 387.

11. Fenn, W. O., The role of potassium in physiological processes. Physiol. Rev., 1940, 20, 377.

12. Lown, B., and Levine, S. A., Current concepts in digitalis therapy. New England J. Med., 1954, 250, 771.

13. Gold, H., Modell, W., Kwit, N. T., Shane, S. J., Dayrit, C., Kramer, M. L., Zahm, W., and Otto, H. L., Comparison of ouabain with strophanthidin-3-acetate by intravenous injection in man. J. Pharmacol. \& Exper. Therap., 1948, 94, 39.

14. Root, M. A., and Chen, K. K., Action of 3-acetylstrophanthidin in isolated mammalian heart. Proc. Soc. Exper. Biol. \& Med., 1953, 84, 131.

15. Doyle, J. T., Wilson, J. S., Lépine, C., and Warren, J. V., An evaluation of the measurement of the cardiac output and of the so-called pulmonary blood volume by the dye-dilution method. J. Lab. \& Clin. Med., 1953, 41, 29.

16. Remington, J. W., and Hamilton, W. F., The evaluation of the work of the heart. Am. J. Physiol., 1947, 150, 292.

17. Batson, H. C., Statistical methods in medical research. Basic Science Notes, Army Medical Service Graduate School, 1951-53, Vol. 3, p. 371. 
18. Regan, T. J., Talmers, F. N., Christensen, R. C., Wada, T., and Hellems, H. K., Myocardial ionic exchange: Effects of strophanthidin in the vagotomized dog. J. Lab. \& Clin. Med., 1955, 46, 943.

19. Gregg, D. E., Coronary Circulation in Health and Disease. Philadelphia, Lea \& Febiger, 1950.

20. Ponder, E., Hemolysis and Related Phenomena. New York, Grune and Stratton, 1948.

21. Crosby, W., and Dameshek, W., The significance of hemaglobinemia and associated hemosiderinuria with particular reference to various types of hemolytic anemia. J. Lab. \& Clin. Med., 1951, 38, 829.

22. Cattell, M., and Gold, H., The influence of digitalis glucosides on the force of contraction of mammalian cardiac muscle. J. Pharmacol. \& Exper. Therap., 1938, 62, 116.

23. Wollenberger, A., The energy metabolism of the failing heart and the metabolic action of the cardiac glycosides. Pharm. Rev., 1949, 1, 311.

24. Bing, R. J., Maraist, F. M., Dammann, J. F., Jr., Draper, A., Jr., Heimbecker, R., Daley, R., Gerard, $\mathbf{R}$., and Calazel, P., Effect of strophanthus on coronary blood flow and cardiac oxygen consumption of normal and failing human hearts. Circulation, 1950, 2, 513.

25 Horváth, I., Király, C., and Szerb, J., Action of cardiac glycosides on the polymerization of actin. Nature, 1949, 164, 792.

26. Robb, J. S., and Mallov, S., Effect of ouabain on actomyosin threads. J. Pharmacol. \& Exper. Therap., 1953, 108, 251.
27. Szent-Györgyi, A., Contraction in the heart muscle fiber. Bull. New York Acad. Med., 1952, 28, 3.

28. Harrison, T. R., and Leonard, B. W., The effect of digitalis on the cardiac out-put of dogs and its bearing on the action of the drug in heart disease. J. Clin. Invest., 1926, 3, 1.

29. Olson, R. E., Roush, G., and Liang, M., Effect of acetyl strophanthidin upon the myocardial metabolism and cardiac work of normal dogs and dogs with congestive heart failure. Circulation, 1955, 12, 755.

30. Cannon, P. R., Frazier, L. E., and Hughes, R. H., Sodium as a toxic ion in potassium deficiency. Metabolism, 1953, 2, 297.

31. Hercus, V. M., McDowall, R. J., and Mendel, D., Sodium exchanges in cardiac muscle. J. Physiol., 1955, 129, 177.

32. Ranney, R. E., Biochemical characteristics of glycerol extracted myocardial fibers. Am. J. Physiol., 1955, 183, 197.

33. Conn, H. L., The effects of digitalis and anoxia on potassium transport in the heart: Correlation with electrocardiographic changes. Clin. Research, 1955, 3, 111.

34. Hellems, H. K., Regan, T. J., Talmers, F. N., Christensen, R. C., and Wada, T., The mode of action of acetyl strophanthidin on the failing human heart. J. Clin. Invest., 1956, 35, 710.

35. Wilde, W. S., O'Brien, J. M., and Bay, I., Effluographic determination of potassium flux in heart muscle as related in time to potential changes (E.C.G.) and contraction event. Circulation, 1955, 12, 788. 